\title{
Fetal dural sinus malformation
}

Kavya S. Kaushik, DNB, Ullas V. Acharya, MD, DM, Rupa Ananthasivan, DMRD, DNB, FRCR, CST (UK), Bhavana Girishekar, DNB, and Pramesh Reddy, DNB

Neurology ${ }^{\circledR}$ 2020;95:452-453. doi:10.1212/WNL.0000000000010446

\section{Correspondence}

Dr. Acharya

ullasva77@gmail.com

Figure 1 Fetal MRI

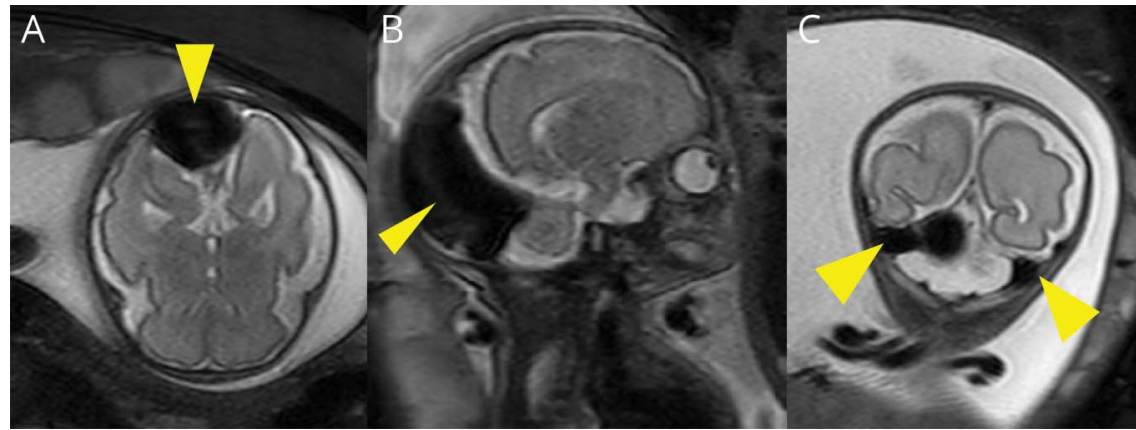

(A-C) Single-shot turbo spin echo sequence images in axial, sagittal, and coronal planes reveal the ectatic torcula, posterior sagittal sinus, and bilateral transverse sinuses, respectively. Flow voids are maintained. No mass effect or hydrocephalus.

A 24-year-old multigravida with no comorbidities underwent anomaly ultrasound at 21 weeks 5 days, followed by fetal MRI, which showed dilation of the torcula, adjacent superior sagittal sinus, bilateral transverse sinuses, and proximal sigmoid sinuses with maintained flow voids (figure 1)

Figure 2 Fetal intracranial 3D gradient recalled echo Dixon-based magnetic resonance angiography

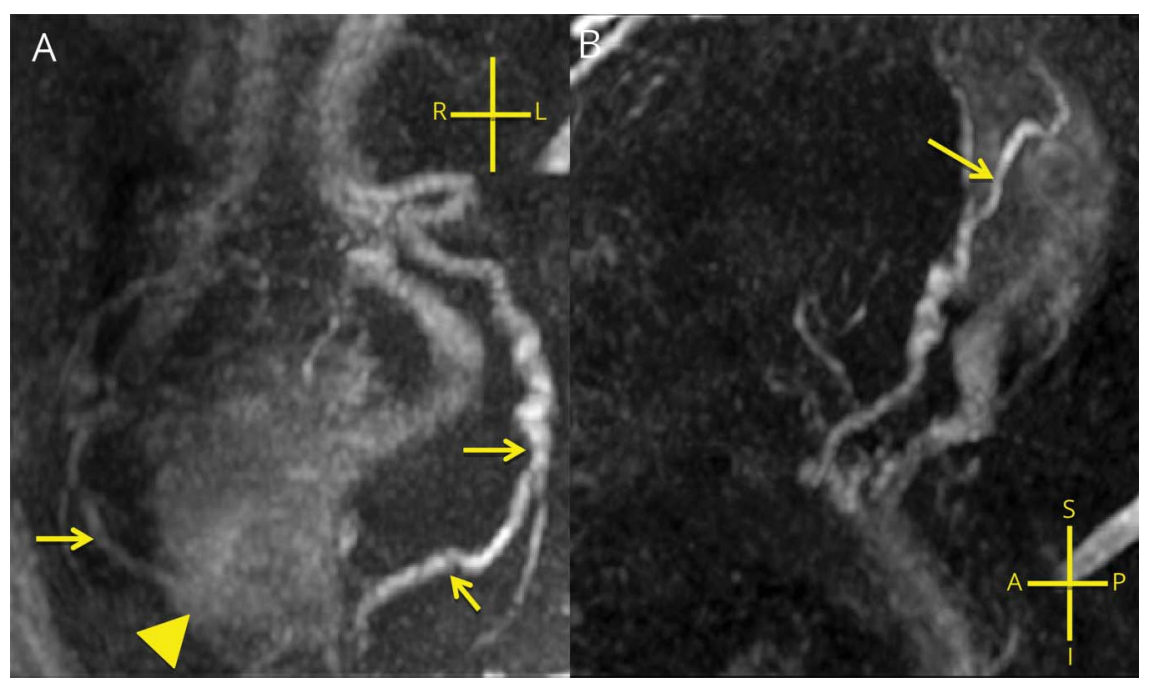

(A, B) Coronal and sagittal maximum intensity projection images depict prominent bilateral occipital arteries (arrows) supplying the dural sinus malformation, which is visualized in the arterial phase (arrowhead).

From the Department of Radiology, Manipal Hospitals, Bengaluru, Karnataka, India.

Go to Neurology.org/N for full disclosures. Funding information and disclosures deemed relevant by the authors, if any, are provided at the end of the article. 
and blood supply to the torcula from bilateral occipital arteries and bilateral posterior cerebral arteries (figure 2), suggesting a diagnosis of nonthrombosed midline type of dural sinus malformation (DSM) in the fetus. ${ }^{1,2}$

DSM should be suspected on prenatal ultrasonography. Prompt fetal MRI must be done to establish the diagnosis, identify intracranial complications, and plan timing, mode of delivery, and postnatal treatment strategy, resulting in better postnatal outcome.

\section{Study funding}

No targeted funding reported.

\section{Disclosure}

The authors report no disclosures relevant to the manuscript. Go to Neurology.org/N for full disclosures.

\section{Appendix Authors}

\begin{tabular}{lll}
\hline Name & Location & Contribution \\
\hline $\begin{array}{ll}\text { Kavya S. Kaushik, } \\
\text { DNB }\end{array}$ & $\begin{array}{l}\text { Manipal } \\
\text { Hospitals, } \\
\text { Bengaluru, } \\
\text { India }\end{array}$ & $\begin{array}{l}\text { Design and conceptualization } \\
\text { of study, major role in } \\
\text { acquisition of data, drafting } \\
\text { and revising the manuscript for } \\
\text { intellectual content }\end{array}$ \\
\end{tabular}

Appendix (continued)

\begin{tabular}{lll}
\hline Name & Location & Contribution \\
\hline $\begin{array}{l}\text { Ullas V. Acharya, } \\
\text { DM, MD }\end{array}$ & $\begin{array}{l}\text { Manipal } \\
\text { Hospitals, } \\
\text { Bengaluru, } \\
\text { India }\end{array}$ & $\begin{array}{l}\text { Design and conceptualization } \\
\text { of study, major role in } \\
\text { acquisition of data, analysis } \\
\text { and interpretation of the data, } \\
\text { critical revision of the } \\
\text { manuscript for intellectual } \\
\text { content }\end{array}$ \\
$\begin{array}{l}\text { Rupa } \\
\text { Ananthasivan, } \\
\text { CST (UK) }\end{array}$ & $\begin{array}{l}\text { Manipal } \\
\text { Hospitals, } \\
\text { Bengaluru, } \\
\text { India }\end{array}$ & $\begin{array}{l}\text { Major role in acquisition of } \\
\text { data, analysis and } \\
\text { interpretation of the data, } \\
\text { critical revision of the } \\
\text { manuscript for intellectual } \\
\text { content }\end{array}$ \\
$\begin{array}{l}\text { Bhavana } \\
\text { Girishekar, DNB }\end{array}$ & $\begin{array}{l}\text { Manipal } \\
\text { Hospitals, } \\
\text { Bengaluru, } \\
\text { India }\end{array}$ & $\begin{array}{l}\text { Major role in acquisition of } \\
\text { data, analysis and } \\
\text { interpretation of the data }\end{array}$ \\
$\begin{array}{l}\text { Pramesh Reddy, } \\
\text { DNB }\end{array}$ & $\begin{array}{l}\text { Manipal } \\
\text { Hospitals, } \\
\text { Bengaluru, } \\
\text { India }\end{array}$ & $\begin{array}{l}\text { Major role in acquisition of } \\
\text { data, analysis and } \\
\text { interpretation of the data }\end{array}$ \\
\hline
\end{tabular}

\section{References}

1. Ebert M, Esenkaya A, Huisman TA, et al. Multimodality, anatomical, and diffusionweighted fetal imaging of a spontaneously thrombosing congenital dural sinus malformation. Neuropediatrics 2012;43:279-282.

2. Rossi A, De Biasio P, Scarso E, et al. Prenatal MR imaging of dural sinus malformation: a case report. Prenat Diagn 2006;26:11-16.

\section{NEW EPISODE}

\section{ค}

$\underset{\text { PoDCAST }}{\text { Neurology }}$

September 8, 2020

\section{Cost-effectiveness of surgery for drug-resistant temporal lobe epilepsy in the US (see p. 430)}

In the first segment, Dr. Jason Crowell talks with Dr. Lara Jehi about her paper discussing surgery costs in temporal lobe epilepsy. In the second part of the podcast, Dr. Dan Ackerman and Dr. Andrew Southerland conclude their discussion on managing ischemic stroke in the 4th of a 4-part series.

Disclosures can be found at Neurology.org.

CME Opportunity: Listen to this week's Neurology Podcast and earn 0.5 AMA PRA Category $1 \mathrm{CME}$ Credits $^{\mathrm{TM}}$ by completing the online Podcast quiz. 


\section{Neurology}

\section{Fetal dural sinus malformation \\ Kavya S. Kaushik, Ullas V. Acharya, Rupa Ananthasivan, et al. Neurology 2020;95;452-453 Published Online before print August 4, 2020 \\ DOI 10.1212/WNL.0000000000010446}

This information is current as of August 4, 2020

\section{Updated Information \&} Services

References

Subspecialty Collections

Permissions \& Licensing

Reprints including high resolution figures, can be found at: http://n.neurology.org/content/95/10/452.full

This article cites 2 articles, 0 of which you can access for free at: http://n.neurology.org/content/95/10/452.full\#ref-list-1

This article, along with others on similar topics, appears in the following collection(s):

\section{Arteriovenous malformation}

http://n.neurology.org/cgi/collection/arteriovenous_malformation MRI

http://n.neurology.org/cgi/collection/mri

Information about reproducing this article in parts (figures,tables) or in its entirety can be found online at:

http://www.neurology.org/about/about_the_journal\#permissions

Information about ordering reprints can be found online:

http://n.neurology.org/subscribers/advertise

Neurology ${ }^{\circledR}$ is the official journal of the American Academy of Neurology. Published continuously since 1951 , it is now a weekly with 48 issues per year. Copyright @ 2020 American Academy of Neurology. All rights reserved. Print ISSN: 0028-3878. Online ISSN: 1526-632X.

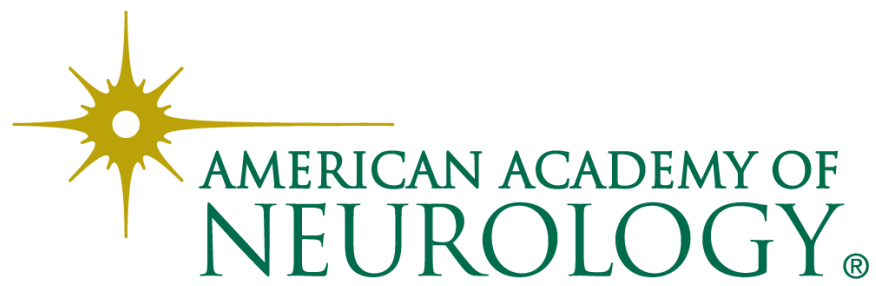

